\title{
Adaptarea activității de judecată în materie civilă în contextul pandemiei și ulterior acesteia
}

Lect. dr. Liviu Gheorghe Zidaru Facultatea de Drept a Universităţii București

\begin{abstract}
Rezumat: Epidemia de SARS-COV2 constituie o provocare semnificativă pentru sistemul judiciar român. Sistemul tradițional, retrograd chiar, în care toate părțile sunt citate la aceeași oră la o ședință de judecată imensă nu mai este practicabil. Sunt necesare reguli procedurale noi, iar fixarea de ore diferențiate pentru cauze diferite, deja o practică curentă în unele instanțe, trebuie să devină noul cotidian, chiar și după pandemie. In plus, Codul de procedură civilă trebuie modificat pentru a permite judecata prin videoconferință și, cu acordul părților, în proceduri exclusiv scrise. Totodată, România trebuie să înceapă procesul complicat de introducere a unui veritabil dosar (administrat) electronic.
\end{abstract}

Cuvinte cheie: justiție civilă, modernizare, pandemie, propuneri de lege ferenda

\section{Adapting civil justice to the pandemic}

Abstract: The SARS-COV2 Pandemic represents a challenge for the Romanian justice system. The traditional approach, where all parties are summoned physically in the court roomand even at the same time -is not sustainable any longer. New procedural rules are necessary. Different hours for different cases is already a reality in many courts and it should become the day-to-day rule. In addition, trials through videoconferences and in written proceedings only should be made possible by the Civil Procedure Code. At the same time, Romania should begin the lengthy process of implementing the electronic file.

Keywords: Civil justice, reform, pandemic, de lege ferenda proposals

\section{Preliminarii}

În cadrul Conferinței online Urgența în drept, organizată de Facultatea de Drept a Universității București în perioada 29-30 martie 2020, la scurt timp după instituirea stării de urgenţă pe teritoriul României ca urmare a pandemiei de coronavirus SARS-COV2, am prezentat o temă intitulată, la acea vreme, Perspectivele reluării treptate a activității de judecată în materie civilă, în condițiile epidemiei și ale stării de urgență.

În acel moment, durata stării de urgență părea sub semnul întrebării. Art. 42 alin.1 din Decretul nr. 195/2020 al Președintelui României privind instituirea stării de urgență pe 
teritoriul țării ${ }^{1}$ prevedea că activitatea de judecată continuă doar în cauzele de urgență deosebită. De aceea, am avansat soluții privind reluarea graduală a activității de judecată chiar în contextul unei stări excepționale, cu modificarea unor dispoziții procedurale şi prioritizarea anumitor tipuri de cauze față de celelalte.

La scurt timp, mi s-a părut că prezentarea și sugestiile pe care le-am schițat acolo sunt în parte depășite de evenimente. Pe de-o parte, pe durata stării de urgență, prelungită până în 15 mai 2020, nu s-a inițiat o reluare treptată a activității în materie civilă, marea majoritate a cauzelor civile fiind suspendate . Este real că lista cauzelor ce se judecă a fost extinsă în mod binevenit de către Consiliul Superior al Magistraturii, după adoptarea Decretului nr. 240/2020 al Președintelui României privind prelungirea stării de urgență2, dar devenise deja vizibil că activitatea de judecată va fi reluată practic integral după data de 15 mai 2020. La data încetării stării de urgență, pandemia părea să fi ajuns la o oarecare acalmie. Totul părea să fi reintrat în normal, fie și cu unele amenajări de ordin organizatoric (e.g., fixarea cauzelor pe ore, o măsură firească în sfârșit aplicată și în instanțele române, purtarea măștilor în timpul ședințelor de judecată).

Instanțele judecătorești, inclusiv Curtea de Apel București, la care îmi desfășor activitatea în calitate de judecător, au făcut eforturi foarte mari pentru a recupera întârzierile cauzate de protestul judecătorilor (cu privire la tentativele de abrogare a pensiilor de serviciu) şi apoi de pandemia cu Covid - 19, fiind programate ședințe de judecată numeroase, cu un număr mai mare de cauze față de media unei activități rezonabile, inclusiv în luna iulie 2020, sistemul judiciar şi Consiliul Superior al Magistraturii fiind de acord că se impune reducerea vacanței judecătorești la o singură lună, tocmai pentru a asigura o judecată fără întârzieri excesive.

Reaprinderea pandemiei în contextul unei relaxări prea abrupte - percepută ca atare de public, care și-a schimbat comportamentul și a revenit la vechile obiceiuri, mai ales estivale - și apariția primelor cazuri de infectare cu Covid 19 printre judecători și personalul instanțelor și al parchetelor ridică însă serioase semne de întrebare cu privire la sustenabilitatea pe termen scurt și mediu a revenirii la modul clasic de desfăşurare a justiției civile. Tot efortul desfășurat în prezent s-ar putea să fie zădărnicit de o nouă suspendare, mai lungă decât prima (de altfel, impresia mea empirică a fost că părțile au intuit acest risc, alegând în general să se judece la termenele acordate după încetarea stării de urgență). Trebuie găsite aşadar soluții pe termen scurt, mediu și lung, altele decât tendința tradițională a judecătorilor de a se supraîncărca cu muncă pentru a salvgarda cât de cât interesele justițiabililor și de a compensa deficiențele de sistem.

Revin așadar cu o variantă actualizată și (con-)textualizată a prezentării mele, cu precizarea că, în opinia mea, justiția civilă din România se desfășoară încă într-o paradigmă tradițională (eufemistic vorbind), numeroase etape de modernizare a dotărilor instanțelor și a reglementărilor aplicabile fiind omise în ultimul deceniu, dacă nu chiar în ultimele

\footnotetext{
${ }^{1}$ Publicat în M.Of. nr. 212/16.03.2020.

${ }^{2}$ Publicat în M.Of. nr. 311/14.04.2020.
} 
două decenii. Reforma legilor justiției din anul 2004 și integrarea în Uniunea Europeană în 2007 au creat impresia înșelătoare că justiția din România a ajuns la nivel european. Din nefericire, de atunci s-au neglijat masiv investițiile în baza materială, nu s-au creat condițiile unei bune aplicări a Noului Cod de procedură civilă (judecata în camera de consiliu fiind prorogată și apoi abrogată), paradigmele clasice ale unei justiții ancorate mai degrabă în secolul al XIX-lea decât al XXI-lea fiind păstrate din inerție și lipsă de viziune. Discursurile rostite rutinat cu diferite ocazii festive de către reprezentanții de frunte ai justiției, ai celorlalte autorități judiciare și ai profesiilor partenere nu pot escamota această realitate puțin convenabilă.

Pandemia a scos la iveală într-o manieră șocantă neajunsurile dotărilor, ale reglementărilor și (poate mai ales a) deprinderilor procesuale din care nu putem sau nu vrem să ieșim, dar a și catalizat o minimă dorință de reformă, vizibilă (măcar) în fixarea orelor diferențiate de soluționare a cauzelor, precum în unele discursuri prudente privind reforme scadente. Este un moment care nu ar trebui ratat, deși nu întrevedem încă suficientă voinţă pentru a-l valorifica.

Încercăm așadar să formulăm propuneri privind modificări ce ar putea fi aduse legislației procesual civile, fie ele temporare sau nu (punctele 3 și 4), nu înainte de a aborda relația activității de judecată cu starea de urgență (punctul 2).

\section{Relația activității de judecată cu starea de urgență: continuarea sau suspendarea activității?}

OUG nr. 1/1999 privind regimul stării de asediu și regimul stării de urgență $\breve{a}^{3}$ a fost adoptată în contextul foarte special al iminentei atacări a instituțiilor statului democratic de către ceea ce se va dovedi a fi ultima mineriadă (cel puțin până în prezent). La mai puțin de un deceniu de la mineriadele din 1990 - 1991, care ne-au situat în afara lumii civilizate și democratice pentru mulți ani, spectrul unei noi mineriade a determinat adoptarea acestui act normativ. Deloc surprinzător aşadar că, de vreme ce redactorii au avut în vedere în epocă un pericol de natură militară ori cvasimilitară, se vorbește despre ordonanțe militare. Bineînțeles că în forma inițială a OUG nr. 1/1999 nu existau dispoziții legale privind activitatea instanțelor judecătorești, neexistând nicio rațiune pentru care instituirea unei stări excepționale precum starea de urgență ori de asediu pentru a combate o insurecție îndreptată împotriva statului de drept să determine ipso iure o suspendare a activității unei puteri în stat, a cărei principală funcțiune o constituie tocmai asigurarea supremației legii, a ordinii de drept și salvgardarea libertăților publice, precum și a drepturilor individuale!

Nu este așadar deloc de mirare că prin Legea mr. 453/2004, de aprobare a OUG nr. 1/1999 s-a inserat un nou art. 3 ind.2, potrivit cu care pe durata stării de asediu și a stării de urgență sunt interzise:

${ }^{3}$ Publicată în M.Of. nr. 22/21.01.1999, aprobată prin Legea nr. 453/2004, publicată în M.Of. nr 1052/12.11.2004. 
a) limitarea dreptului la viață, cu excepția cazurilor când decesul este rezultatul unor acte licite de război;

b) tortura și pedepsele ori tratamentele inumane sau degradante;

c) condamnarea pentru infracțiuni neprevăzute ca atare, potrivit dreptului național sau internațional;

d) restrângerea accesului liber la justiție.

Așadar, legiuitorul a prevăzut tentația restrângerii accesului la justiţie în contextul stării de urgență ori de asediu și a considerat că acesta este prea important pentru a fi supus restrângerii, alături de alte valori fundamentale (supraordonate) ale statului de drept, precum dreptul la viaţă, interzicerea torturii, principiul nullum crimen sine lege etc.

Această reglementare (de altfel neabrogată expres) este la rândul ei prea rigidă în măsura în care este interpretată că se opune oricărei restrângeri a accesului liber la justiţie, căci în contextul unei stări de urgență determinate de riscul ridicat de contagiune cu un virus periculos anumite restrângeri ale dreptului de acces la justiție se vădesc a fi indispensabile, mai ales în contextul în care, la începutul anului de grație 2020, procedurile judiciare în România se desfășurau așa cum le cunoaștem cu toții: cu citare în aproape toate cauzele, părțile fiind chemate de regulă la aceeași oră; săli de ședință, arhive și registraturi foarte aglomerate; cu numeroși justițiabili care se deplasează personal la proces, alături de avocați ori chiar fără avocați, asistența avocaţială nefiind obligatorie în fața niciunei instanțe din România (situație care ne singularizează negativ pe plan european) $)^{4}$. Era așadar evident că procedurile judiciare nu pot continua astfel fără a risca o explozie de infecții ale căror focare s-ar fi găsit tocmai în instanțe și parchete.

De aceea, în sensul art. 53 din Constituție, restrângerea dreptului de acces la justiție prin decretul Președintelui de instituire a stării de urgență apare ca fiind o măsură justificată și necesară, maximul de atenție fiind cerut în zona testului de proporționalitate.

După cum am arătat deja, art. 42 alin.1 din Decretul nr. 195/2020 prevedea că pe durata stării de urgență, activitatea de judecată continuă în cauzele de urgență deosebită. Lista acestor cauze se stabilește de Colegiul de conducere al Înaltei Curți de Casație și Justiţie pentru cauzele de competența acesteia și, respectiv, de colegiile de conducere ale curților de apel pentru cauzele de competența lor și pentru cauzele de competența instanțelor care funcționează în circumscripția lor teritorială, putând fi, după împrejurări, actualizată. Consiliul Superior al Magistraturii dă îndrumări, în vederea asigurării unei practici unitare, colegiilor de conducere ale instanțelor menționate cu privire la modul de stabilire a

\footnotetext{
${ }^{4} \mathrm{Cu}$ privire la această problemă, a se vedea V.M. Ciobanu, G. Boroi, F.A. Baias, T.C. Briciu, C.C. Dinu, L.Gh.Zidaru „Consideratii privind constituționalitatea dispozițiilor din noul Cod de procedură civilă care stabilesc asistența avocațială obligatorie în recurs", în Revista Română de Drept Privat nr. 3/2014 (studiu disponibil și pe www.juridice.ro).
} 
cauzelor care se judecă pe durata stării de urgenţă. Textul a fost preluat aidoma în cuprinsul art. 63 alin. 1 din Decretul nr. 240/2020, prin care starea de urgență a fost prelungită.

Personal, găsesc că restrângerea judecării cauzelor civile la cele de urgență deosebită, după cum s-a dispus prin decretele prezidențiale menționate și s-a reglementat ulterior (destul de restrictiv) prin hotărâri ale Consiliului Superior al Magistraturii este o măsură severă. Ea a fost justificată de contextul pandemic, dar pe de altă parte, este greu de imaginat într-un stat de drept că o restrângere atât de drastică poate fi susținută pe durata mai multor luni (a fortiori, pe o perioadă și mai lungă). Nu punem în discuție legitimitatea constituțională a soluției adoptate ${ }^{5}$ și nici justețea ei în contextul dat la momentul respectiv, ci relevăm că o restrângere atât de drastică s-a dovedit necesară tocmai din cauza stării justiţiei la momentul respectiv, procedurile judiciare fiind insuficient de flexibile pentru a

${ }^{5} \mathrm{Cu}$ privire la această problemă, a se vedea B. Dima, Care este natura juridică a decretelor
Presedintelui României emise pentru instituirea si prelungirea stării de urgentă?, studiu publicat pe www.drept.unibuc.ro (https://drept.unibuc.ro/Forum-juridic-s938-ro.htm - Forum juridic al Analelor Universității din București - seria Drept).

„A Analizând conţinutul celor două decrete ale Președintelui României emise pentru instituirea, respectiv prelungirea stării de urgență, am observat că acestea cuprind o serie de măsuri care organizează executarea dispozițiilor OUG nr. 1/1999 și particularizează/adaptează respectivele dispoziții la anumite domenii de activitate esenţiale pentru gestionarea crizei sanitare provocate de COVID-19 (sănătate, economie, justiţie, educaţie, achiziții publice etc.). Chiar și măsurile urgente cu aplicabilitate graduală din Anexa 2 a celor două decrete, care vizează restrângerea exercițiului unor drepturi și libertăți fundamentale ale cetățenilor, sunt măsuri de organizare a executării dispozițiilor art. 20 din OUG nr. 1/1999, întrucât particularizează/adaptează/identifică, prin raportare la situația de fapt existentă, care sunt drepturile și libertățile fundamentale al căror exercițiu se restrânge în temeiul legii. Altfel spus, nici decretele Președintelui, nici ordonanțele militare emise în temeiul OUG nr. 1/1999 nu reglementează cu titlu primar restrângerea exercițiului unor drepturi și libertăți fundamentale. Această restrângere a fost deja reglementată la nivel primar prin actul normativ OUG nr. 1/1999 aprobat prin Legea nr. 453/2004. Așadar, cum se poate considera că Președintele României reglementează primar restrângerea unor drepturi și libertăți prin decretul prezidențial când legea pe care o pune în aplicare raportat la situația de fapt a reglementat deja cu titlu general și temporar (doar pe perioada stării de urgență) restrângerea exercițiului unor drepturi și libertăți? Dacă sunt neclare sau imprecise dispozițiile OUG nr. 1/1999 prin care s-a reglementat restrângerea exerciţiului unor drepturi sau libertăți fundamentale, dacă respectă sau nu condițiile prevăzute la art. 53 din Constituție sunt aspecte pe care le poate verifica doar Curtea Constituțională. Însă, într-un asemenea caz, trebuie înțeles și faptul că legislația care prevede regimul juridic al stării de excepție presupune în mod invariabil un grad de generalitate mai mare decât legislația aplicabilă în perioada de normalitate, tocmai pentru că particularitățile stării de excepție sunt excepționalitatea și imprevizibilitatea pericolului care afectează atât societatea în ansamblul său, cât și fiecare individ în parte. Nu este întâmplător faptul că însăși CEDO prevede în art. 15 posibilitatea adoptării de măsuri derogatorii de la Convenție în caz de război sau de alt pericol public ce ameninţă viaţa naţiunii." Considerentele 86-90 ale Deciziei Curții Constituționale nr. 152/6.05.2020, publicată în M.Of. nr. 287/13.05.2020 reiau aproape întocmai opinia pertinentă exprimată de dl. profesor Bogdan Dima. 
permite judecătorului să opteze pentru soluționarea cauzelor fără citare ori prin videoconferință, bunăoară.

La data conferinței Urgența în drept, apreciam că suspendarea majorităţii proceselor este necesară pentru a preveni un focar de pandemie și pentru corelare cu restricțiile de circulație impuse cu câteva zile anterior prezentării mele. Totodată însă, atrăgeam atenția că efectele suspendării accesului la justiție pot fi foarte grave pentru drepturile persoanelor, circuitul civil, economie (suspendarea litigiilor între profesioniști, de achiziții publice etc.) și statul de drept (dar și pentru profesiile juridice, ca cea de avocat), o atare suspendare nefiind acceptabilă și sustenabilă decât pe termen scurt. Avansam la acea dată ideea reluării graduale a activității de judecată, chiar anterior expirării stării de urgență, reluare graduală posibilă însă doar în contextul instituirii unor reguli de procedură cu caracter derogatoriu.

Din păcate, în loc să găsească metode de a compatibiliza fie și temporar condiţiile de desfășurare a proceselor civile cu condițiile impuse de pandemie, pentru a permite reluarea cât mai multor procese chiar și în timpul stării de urgență impuse din motive de sănătate publică, legiuitorul a mers în direcția opusă, adoptând Legea nr. 120/2020 pentru completarea Legii nr. 304/2004 privind organizarea judiciară ${ }^{6}$, prin care a impus, practic o suspendare ope legis a activității de judecată pe durata stării de urgență și de asediu.

Astfel, potrivit art. $11^{1}$ din Legea nr. 304/2004, introdus prin această lege,

(1) Activitatea de judecată se suspendă pe perioada decretării stării de asediu sau a stării de urgenţă, în condiţiile art. 93 din Constituţia României. $\quad$ (2) Pe durata stării de asediu sau a stării de urgenţă, activitatea de judecată poate continua doar în situaţii excepţionale, de urgenţă deosebită, temeinic justificate, referitoare la protecţia relaţiilor de familie şi la măsurile dispuse prin decret emis de Preşedintele României cu privind la instituirea stării excepţionale. (3) Cauzele care se vor judeca pentru fiecare categorie de instanţe vor fi stabilite, în mod exhaustiv, doar de Consiliul Superior al Magistraturii, după consultarea colegiilor de conducere ale curților de apel, pentru curţile de apel, tribunale şi judecătorii, respectiv a Colegiului de conducere al Înaltei Curţi de Casaţie şi Justiţie. (4) Pe durata stării de asediu sau a stării de urgenţă, în cauzele în care s-a dispus măsura arestării preventive sau în cauzele în care părţile execută pedeapsa în regim privativ de libertate, şedinţele de judecată se vor desfăşura prin videoconferinţă. (5) Pe durata stării de asediu sau a stării de urgenţă, termenele de prescripţie, cele procedurale şi cele de decădere nu încep să curgă, iar, dacă au început să curgă, se suspendă.

Această soluție este susceptibilă de serioase rezerve.

Întâi, starea de urgenţă poate să nu fie impusă de o pandemie sau de alte împrejurări care privesc sănătatea publică, ci de o dezordine socială accentuată, revolte, proteste violente, eventual starea de război cu care România s-ar afla cu alt stat etc. În toate aceste din urmă cazuri, ni se pare că buna funcționare a justiției este esențială - cel mult se pot lua măsuri de siguranță suplimentare și, eventual, restrânsă activitatea instanțelor din zona

${ }^{6}$ Publicată în M.Of. nr. 608/10.07.2020. 
afectată de conflicte și tulburări, însă în rest ni se pare că suspendarea activităţii unei puteri în stat tocmai în contexte în care justiția poate fi și mai necesară ca în mod normal este o soluţie din principiu de neadmis.

Doi, rezultând din cele ce preced, impunerea rigidă a suspendării activității de judecată (cu excepții nesemnificative și neclare, după cum vom arăta) este o soluție nu doar neoportună - căci trebuie văzut de la caz la caz dacă motivul care a determinat instituirea stării de urgență impune sau nu măsuri derogatorii cu privire la activitatea instanțelor (e.g., o mineriadă credem că nu impune suspendarea activității instanțelor, ba chiar dimpotrivă!) - ci și neconstituțională din perspectiva art. 21 din Constituție, dar și a art. 53 din Constituție, căci soluția suspendării cvasitotale a activității judiciare fără niciun test concret de proporționalitate apare ca fiind contrară textelor evocate. Surprinde cu atât mai mult că această iniţiativă legislativă nu a trezit niciun fel de reacție până în prezent.

Trei, soluția legislativă conținută de nou introdusul art. $11^{1}$ din Legea de organizare judiciară nr. 304/2004 este neclară sub mai multe aspecte.

În ce privește alin.1, este neclar dacă instituirea regională a stării de urgență ori de asediu determină suspendarea activității judiciare doar în acea zonă ori în întreaga țară (ceea ce în tot cazul ar fi exorbitant și nejustificat). Apreciem că interpretarea corectă este cea restrictivă, dar textul trebuia să fie limpede în această privință.

În ce privește alin.2, legiuitorul pare animat de grija de a restrânge la extrem orice posibilitate de a lărgi sfera cauzelor ce se judecă în perioada stărilor de urgență și de asediu, de vreme ce menționează doar protecția relațiilor de familie și (parțial neclar) judecățile în legătură cu măsurile impuse prin decretul Președintelui. Dar dacă se săvârșește - în afara relațiilor de familie - un viol, o vătămare corporală gravă sau chiar o crimă, o distrugere în formă agravată a unor bunuri (prin incendiere) ori un atac terorist? Se pot judeca aceste infracțiuni, se pot dispune măsuri preventive în ce le privește? Un exemplu banal care relevă slăbiciunea fundamentală a oricărei încercări de a enumera prin lege cauzele care se vor judeca, a fortiori a unei enumerări vădit lacunare. Ordinele de protecție (la care probabil s-a gândit legiuitorul) nu epuizează sfera cauzelor de urgenţă deosebită necesare a fi judecate în starea de urgență ori de asediu, credem noi.

Trecând peste tautologia conținută de alin.3 (...vor fi stabilite exhaustiv, doar de...) este neclar dacă alin.3 conține o altă categorie de cauze ce pot fi judecate în starea de urgență ori de asediu, care se adaugă celor prevăzute de alin.2 (și care sunt vădit insuficiente). Pledăm pentru această variantă de interpretare din rațiuni pragmatice, însă ni se pare că alin.3 este deficitar - dacă se intenționa să se poată adăuga și alte cauze decât cele arătate la alin.2, trebuia să se prevadă expres aceasta, iar dacă se intenționa contrariul, nu vedem exact ce sens mai are alin.3, în general, căci C.S.M. s-ar vedea pus în situația de a consacra prin hotărârea sa ceea ce alineatul precedent spune oricum.

În ce privește alin.4, pare de asemenea un text lacunar - evident, legiuitorul a redactat textul sub impresia pandemiei cu virusul SARS-COV2 și al textelor din Decretele de instituire, respectiv prelungire a stării de urgență, dar, repetăm, ce ne facem cu cauze 
diferite de instituire a stării de urgență (e.g., mineriadă sau tulburări sociale accentuate în sudul țării - este obligatoriu să se desfășoare prin videoconferință cauzele cu arestați preventiv din Cluj sau Iași?). Este permisă videoconferința și în alte situații?

În fine, nu avem nimic de reproșat alineatului 5, în măsura în care este interpretat că se aplică dosarelor afectate de măsura suspendării.

Patru, din perspectiva regulilor de tehnică legislativă - și pe care Curtea Constituțională le uzitează adesea drept criterii de evaluare a standardelor statului de drept, care reclamă reguli clare, precise, previzibile și necontradictorii - este eronată soluția de a reglementa un aspect al stării de urgență și de asediu în afara OUG nr. 1/1999, în cuprinsul Legii de organizare judiciară, cu atât mai mult cu cât art. $11^{1}$ din Legea de organizare judiciară contrazice în mod evident dispozițiile art. $3^{2}$ lit.d) din OUG nr. 1/1999, aprobată prin Legea nr. 453/2004, care, reamintim interzic orice restrângere a dreptului de acces liber la justiţie în timpul stărilor de urgență și de asediu - text oricum mult mai întemeiat la nivel de principiu decât noua lege - pe care însă nu le abrogă, ceea ce poate genera confuzie și insecuritate juridică. Asemenea paralelisme și incongruențe legislative au atras adesea decizii de constatare a neconstituționalității textelor astfel adoptate.

Cinci, deși în acest moment nu există repere concrete pentru un atare pericol - o reglementare trebuie totuşi gândită pentru orice ipoteze viitoare - recenta modificare creează (la limită) pericolul ca Președintele să instituie starea de urgență, iar Parlamentul să o aprobe tocmai în scopul suspendării unor procese care, deși nu sunt de urgență deosebită, prezintă totuși o importanță deosebită (de ordin economic, social, politic, precum procese penale îndreptate împotriva unor persoane cu înalte funcții în stat, achiziții publice de importanță națională etc.). Acest scenariu care pare în prezent științificofantastic nu ne poate lăsa, totuși, indiferenți, anii trecuţi demonstrând că ne putem confrunta fie și potențial cu situații cândva de neînchipuit (bunăoară, nu credem că legiuitorul constituant, atunci când a reglementat constituțional ordonanța de urgență, respectiv retroactivitatea legii penale mai favorabile, a anticipat ori dorit în vreun fel dezincriminarea ori amnistia pentru infracțiuni de drept comun prin ordonanță de urgență).

În fond, printr-una din primele sale decizii (nr. 6/1992) Curtea Constituțională a statuat în termeni fermi că legiuitorul nu poate suspenda ori împiedica activitatea instanțelor judecătorești: ,, Cea de-a treia normă legală considerată ca neconstituțională prin sesizarea Curții Supreme de Justiție se referă la art. 5, potrivit căruia, pînă la adoptarea viitoarei legi se suspendă din oficiu judecarea proceselor de orice natură privitoare la bunurile ce fac obiectul art. 1 din legea în discuție (bunuri naționalizate ori preluate în orice fel de regimul comunist - n.n.), precum și executarea hotărîrilor judecătorești definitive pronunțate cu privire la asemenea bunuri.

Această prevedere încalcă raporturile constituţionale dintre puterea legislativă și cea judecătorească. În virtutea principiului separației puterilor în stat, Parlamentul nu are dreptul să intervină în procesul de realizare a justiției. Dreptul de control al Parlamentului se exercită și asupra modului cum funcționează organele puterii judecătorești, el stabilind, în acest scop, regulile după care se desfăşoară activitatea de 
judecată. Potrivit Constituției, acest drept, însă, se poate exercita numai cu respectul autorității lucrului judecat și fără a împiedica instanțele judecătorești de a-și exercita misiunea lor, prevăzută de art. 125 din Constituție, de realizare a justiției. O imixtiune a puterii legislative care ar pune autoritatea judecătorească în imposibilitatea de a funcționa, chiar dacă numai cu referire la o anumită categorie de cauze și pentru o anumită perioadă de timp, ar avea drept consecință ruperea echilibrului constituțional dintre aceste autorități. De aceea, o dispoziție legală prin care se suspendă cursul judecății sau executarea hotărîrilor judecătorești definitive referitoare la anumite cauze determinate este neconstituțională (s.n.).

Cele arătate nu exclud posibilitatea autorităților judecătorești ca, în condițiile legii, să suspende judecata sau executarea unei hotărîri judecătorești, precum și, în cazul exercitării căilor de atac, să desființeze sau să modifice o hotărîre care nu ar fi legală sau temeinică."7

Credem că ceea ce s-a decis în mod judicios încă din 1992 este întrutotul valabil și în anul 2020.

Apreciem prin urmare că această lege adoptată conjunctural trebuie revăzută și, de ce nu, ar trebui să fie supusă examinării instanței constituționale (eventual de către Avocatul Poporului, care a dat dovadă de multă atenție cu privire la alte restrângeri ale drepturilor constituționale în această perioadă - nu vedem de ce accesul la justiție nu ar beneficia de o atenție similară).

În fine, remarcăm că dacă pe durata stării de urgență și de asediu soluția spre care tinde legiuitorul (în sens larg, incluzând aici și Președintele ca autor al Decretelor de instituire, respectiv de prelungire a respectivelor stări) constă generic suspendarea judecăților, în cazul stării de alertă (care reprezintă tot o stare excepțională atenuată), Legea nr. 55/2020 privind unele măsuri pentru prevenirea şi combaterea efectelor pandemiei de COVID-198 nu mai prevede, în mod curios, nimic cu privire la posibila restrângere a activității de judecată în materie civilă, deși dedică articole întregi insolvenței și executării pedepselor și altor măsuri dispuse în procesul penal ${ }^{9}$.

În ce ne privește, restrângerea dreptului de acces la justiţie este principial posibilă în stările excepționale (de urgență, de asediu, de alertă), dar în condiții prevăzute clar și coerent prin lege și cu un prealabil test de proporționalitate la adoptarea acestei măsuri,

\footnotetext{
${ }^{7}$ Am păstrat grafia originală a hotărârii, anterioară modificărilor propuse de Academia Română în anul 1993.

${ }^{8}$ Cunoscută și sub denumirea de Lege a stării de alertă - M.Of. nr. 396/15.05.2020.

${ }^{9} \mathrm{Cu}$ titlu de curiozitate, legiuitorul stării de alertă a avut totuși grija să suspende concursurile de ocupare a tuturor funcțiilor vacante din sectorul public, cu puține excepții (art. 27 alin.3 din Legea nr. 55/2020), ceea ce a generat incertitudine și cu privire la examenul de capacitate al judecătorilor și procurorilor stagiari, respectiv examenul de ocupare a funcțiilor de conducere în instanțe și parchete (Consiliul Superior al Magistraturii a apreciat inițial că acestea sunt suspendate, apoi a dispus reluarea lor); într-un mod aproape anecdotic, au fost suspendate și toate concursurile pe posturi didactice vacante, inclusiv în universități. A fost nevoie de o lege specială pentru a înlătura această anomalie - Legea nr. 103/2.07.2020, publicată în M.Of. nr. 583/2.07.2020.
} 
activitatea de judecată urmând a fi restrânsă cât mai puțin posibil. Consiliul Superior al Magistraturii pare cel mai bine plasat pentru a decide, în mod unitar și fără alte îngrădiri legale, ce cauze se judecă și ce nu pe parcursul stărilor excepționale (ale căror acte normative trebuie să reglementeze în termeni clari condițiile în care se poate dispune restrângerea activităţii de judecată, principala condiţie fiind cea a necesității în concret a unei atare măsuri în raport de un risc determinat, precum cel epidemic), după consultarea instanțelor judecătorești. Din această perspectivă, credem că Legea nr. 120/2020 ar fi trebuit doar să dea în competența Consiliului Superior al Magistraturii restrângerea motivată a activității de judecată pe durata stărilor de urgență, de asediu ori de alertă, dacă pericolul care a determinat instituirea stării excepționale impune aceasta și numai în măsura strict necesară. Legea comite un exces prin reglementarea directă a suspendării, indiferent de cauzele care au determinat instituirea stării de urgenţă ori de asediu.

În principiu însă, soluția optimă, dezirabilă nu este restrângerea (suspendarea) activităţii instanțelor, ci adaptarea acesteia noilor condiții. Două abordări sunt posibile, de altfel într-o manieră complementară. În primul rând, se pot adopta măsuri legislative limitate în timp, aplicabile pe durata pandemiei și o perioadă de timp ulterioară, pentru a scădea stocul de dosare acumulate și a reveni treptat la normal, recuperând întârzierile. În al doilea rând, se pot iniţia reforme pe termen lung ale justiției civile (nu ne ocupăm de cea penală în cele ce urmează) pentru ca situații similare să nu ne mai găsească într-o situație de vulnerabilitate atât de mare ca în prezent.

\section{Măsuri temporare ce pot fi luate în vederea desfășurării activității de judecată în contextul pandemic actual}

Pentru a nu modifica intempestiv Codul de procedură civilă, anumite măsuri speciale pot fi adoptate de urgență și testate în contextul unei perioade de risc epidemic mai lungi decât starea de urgență ori de alertă în sine.

Având în vedere specificul pandemiei cu virusul SARS-COV2, scopul urmărit prin aceste măsuri temporare este de a reduce riscul contagiunii, prin reducerea cât mai mult posibil a deplasării justițiabililor la instanțe, dar fără a suspenda judecarea cauzelor ori cel puțin a majorității cauzelor.

Aceste măsuri, schițate în prezentarea mea din data de 29.03.2020, sunt în continuare actuale, dat fiind riscul real ca starea de urgență să fie reinstituită pentru o perioadă chiar mai lungă decât cea din această primăvară ori, cel puțin, ca starea de alertă să continue întro formă agravată, cu restricții mai severe (precum carantine zonale). Revenirea valului pandemic și primele cazuri de coronavirus printre judecători și personalul instanței ne arată că suntem încă foarte departe de o desfășurare în condiții normale a activității de judecată și că opriri fie și temporare ale activităţii unor instanțe devin posibile, dacă nu chiar probabile.

Prima măsură și care ni se pare în afară de orice discuție, fiind subînțeleasă, privește luarea unor măsuri permanente de protecție sanitară: măști, vizete, mănuși, dezinfectant pt personalul instanței și pentru justițiabili, dezinfectare periodică și frecventă. Totodată, la 
unele instanțe s-au adoptat măsuri precum montarea de plexiglas la pupitrul judecătorilor, respectiv cele ale avocaților, care se pot dovedi eficiente în condițiile unor investiții minimale (e drept, chiar și acestea greu de obținut). Acestea ar trebui generalizate. Purtarea măștilor în incinta instanțelor de către toate persoanele trebuie impusă și urmărită cu strictețe.

Celelalte măsuri privesc procedura judiciară, respectiv funcționarea instanțelor ca serviciu public.

Din perspectiva procedurii judiciare, principala măsură pe care o sugerăm se referă la judecarea unui număr sporit de cauze fără citarea părţilor.

Reamintim că în Codul de procedură civilă există o procedură simplificată în care citarea părților este facultativă, fiind lăsată la aprecierea instanțelor, respectiv cererile cu valoare redusă (art. 1.026 - 1.033 C.pr.civ.), care transpun în raporturile procesuale pur interne dispozițiile Regulamentului de stabilire a unei proceduri europene privind cererile cu valoare redusă ${ }^{10}$.

În prezent, procedura este alternativă cu cea de drept comun și este deschisă pentru cererile având o valoare de până la 10.000 lei inclusiv (doctrina fiind în sensul că acest plafon se referă la capătul principal de cerere). Acest plafon a fost stabilit prin raportare la plafonul de 2.000 de euro, prevăzută de prima formă a Regulamentului european privind cererile cu valoare redusă; notăm cu titlu informativ (căci actul european se aplică de sine stătător, fără transpunere internă, însă numai procedurilor cu elemente de extraneitate) că plafonul valoric a fost majorat în anul 2015 până la suma de 5.000 de euro, fără a include accesoriile.

De lege ferenda, s-ar putea institui temporar obligativitatea folosirii procedurii speciale pentru cereri cu valoare redusă pentru toate creanțele în valoare de până la 30.000 lei inclusiv, precum și pentru pentru pensii de întreținere și alte prestații periodice (chirii, abonamente etc.).

Printr-o normă specială ar urma să se prevadă că procedura este obligatorie pentru toate procesele începute până la data de 1.12.2021 (sau altă data considerată relevantă) având ca obiect realizarea unei creanțe care nu depășește suma de 30.000 lei (sau 50.000 lei, de apreciat ca oportunitate legislativă), fără a se lua în considerare dobânzile, penalitățile ori alte accesorii.

Mărirea plafonului și obligativitatea de a recurge la această procedură ar asigura judecarea cu celeritate a marii majorități a dosarelor cu miză patrimonială din circuitul civil (ne referim aici desigur la un criteriu cantitativ, nu mai puțin important, căci este vorba cu

${ }^{10}$ Regulamentul (CE) nr. 861/2007 al Parlamentului European și al Consiliului de stabilire a unei proceduri europene cu privire la cererile cu valoare redusă, amendat prin Regulamentul nr. 2014/2421, forma consolidată fiind disponibilă pe www.eur-lex.europa.eu (https://eurlex.europa.eu/legal-content/EN/TXT/?uri=CELEX:02007R0861-20170714, pagină vizitată la 19.07.2020). 
precădere despre creanțele întreprinderilor mici și mijlocii, ale asociațiilor de proprietari, ale furnizorilor de utilităti în măsura în care facturile emise nu sunt titluri executorii etc.), plafonul de 30.000 de lei fiind unul destul de ridicat. De altfel, procedura specială este una foarte avantajoasă, ea instituind o procedură exclusiv ori preponderent scrisă, citarea este facultativă, prevederile procedurale sunt simplificate și flexibile, hotărârea primei instanțe este executorie, sentințele judecătoriei se atacă numai cu apel, taxa de timbru este fixă. Pentru a stimula atractivitatea procedurii în cazul în care aceasta rămâne facultativă, taxa de timbru poate fi redusă tot temporar la 50 lei.

Desigur, în ipoteza în care procedura devine obligatorie, trebuie derogat de la regula neadministrării probelor excesiv de costisitoare în raport de natura litigiului (art. 1.030 alin.9 teza finală C.pr.civ.), care, ni se pare nouă, este și de lege lata doar o recomandare pentru instanță, căci în dubiu probele necesare trebuie oricum administrate chiar și în procedura cererilor cu valoare redusă. Totodată, reclamantul ar avea libertatea de a folosi formularele puse la dispoziție în cadrul procedurii speciale ori de a formula cerere de chemare în judecată în condițiile dreptului comun, procedura specială fiind aplicabilă ope legis, indiferent de textele de lege invocate de titularul cererii.

Soluția măririi plafonului ni se pare dezirabilă în mod permanent (în plaja 20.000 40.000 lei), în vreme ce instituirea caracterului obligatoriu ar trebui să se facă doar temporar, pentru o perioadă de 1-2 ani, cu reevaluarea soluției la finalul perioadei (suficient de lungi pentru a permite o evaluare relevantă).

În ceea ce privește extinderea posibilității de soluționare a altor cauze supuse procedurii contencioase de drept comun fără citarea părților, două abordări sunt posibile: una mai extinsă și temporară, pe care o vom trata în cele ce urmează, precum și una permanentă și mai moderată, pe care o vom trata în cadrul punctului următor.

$\mathrm{Cu}$ titlu temporar, în context pandemic și post-pandemic (căci stocul însemnat de dosare creat în câteva luni de restrângere a activității se poate rezolva ulterior într-un an sau doi, dacă toate cauzele trebuie judecate doar în ședință publică), se poate institui obligația ca partea să indice expres și motivat dacă solicită ca pricina să fie judecată cu citarea părților; în caz contrar, se prezumă că partea este de acord cu soluționarea cauzei fără citare, pe temeiul înscrisurilor de la dosar și a probelor propuse. Dacă se solicită citarea sau dacă apreciază necesar, ar urma să se permită, alternativ, desfăşurarea ședinței prin videoconferințăa dacă instanța dispune în acest sens, ținând cont de toate circumstanțele cauzei și ale desfășurării activității judiciare; desigur, în această din urmă ipoteză, instanța poate dispune și desfășurarea procesului în ședință obișnuită.

În caz contrar (dacă citarea nu se solicită expres și motivat și nici nu este apreciată necesară din oficiu), instanța poate soluționa cauza fără citarea părților; în aceste cauze, toate încheierile se vor comunica din oficiu părților prin e-mail. Se va institui obligativitatea indicării unei adrese de e-mail pentru comunicarea tuturor citațiilor și actelor de procedură, desigur cu posibilitatea ca partea să indice motivat instanței că solicită comunicarea pe cale clasică (e.g., nu deține mijloace de comunicare electronică ori nu este 
familiarizată cu ele). În acest context, trebuie finalizată efectiv dotarea instanțelor cu semnături electronice (obligatorie oricum după Legea nr. 310/2018 pentru modificarea Codului de procedură civilă şi a altor acte normative ${ }^{11}$ ) și prevăzută comunicarea hotărârilor în format electronic părților, prin e-mail.

Aceste reguli ar profita și Curții Constituționale, Codul de procedură civilă fiind dreptul comun pentru procedurile jurisdicționale reglementate de Legea nr. 47/1992 privind organizarea și funcționarea Curții Constituționale ${ }^{12}$. Ne putem reaminti că pe durata stării de urgență Curtea Constituțională nu a ținut cel puțin inițial niciun fel de ședință, ceea ce, ca și în cazul instanțelor judecătorești, este foarte chestionabil din perspectiva protecției jurisdicționale a drepturilor fundamentale; explicația acestei măsuri (perfect raționale din perspectivă sanitară) constă tocmai în citarea părților în fața Curții, în toate cazurile, soluție excesivă și fără corespondent în alte legislații europene.

Din perspectiva funcționării justiției ca serviciu public, în perioada de pandemie (cel puțin) trebuie extins cât mai mult accesul electronic la piesele dosarului (soluție care va rămâne desigur câștigată) și restrâns semnificativ accesul fizic la registraturi și arhive.

Desigur, spre deosebire de data prezentării mele în cazul conferinței Urgența în drept (29.03.2020), știm că până acum legiuitorul a dat dovadă de pasivitate, chiar dezinteres pentru a reglementa aceste aspecte fundamentale pentru eficiența și siguranța procedurilor judiciare (cu excepția Decretelor de instituire, respectiv de prelungire a stării de urgență, și ele timide în a inova, ceea ce este de altfel de înțeles în raport de limitările inerente acestui tip de act administrativ normativ). Singura măsură luată, doar temporar, de Consiliul Superior al Magistraturii (și încă cu discuții) a fost o derogare temporară de la Regulamentul de ordine interioară, impunându-se ceea ce legea prevede oricum, respectiv fixarea termenelor pe ore (intervale orare). Nu înțelegem deloc de ce măcar în această privință nu a fost pur și simplu modificat Regulamentul de ordine interioară, în sensul de a fi respectate dispozițiile art. 215 alin.1 teza finală C.pr.civ.

Această soluție elementară rezultă oricum în mod imperativ din art. 215 alin.1 C.pr.civ. (în vigoare) și a adus un plus de calitate actului de justiție, experiența tuturor colegilor care au adoptat acest mod de lucru fiind că se asigură dezbateri sobre, aplicate, fără timpi de așteptare pentru avocați și părți (sau cu o așteptare rezonabilă, adesea doar de câteva minute). Nu există niciun temei pentru a nu generaliza acest mod de lucru specific tuturor celorlalte state europene, pandemie sau nu - și, de altfel, acesta se află deja la îndemâna fiecărui judecător, însă ar fi dezirabilă legiferarea clară a unui standard minim aplicabil tuturor proceselor din România.

\section{Modificări legislative fără caracter temporar}

O altă abordare, poate chiar mai eficientă pe termen mediu și lung, constă în găsirea unor soluții echilibrate care pot fi inserate chiar în Codul de procedură civilă, cu titlu de

\footnotetext{
11 Publicată în M.Of. nr. 1074/18.12.2018.

12 Republicată în M.Of. nr. 807/3.12.2010.
} 
drept comun, influențând astfel (în bine) eficiența procedurilor judiciare, fără a impieta asupra echității lor și asupra respectării principiilor fundamentale.

Un prim aspect privește o intervenție punctuală pentru a accentua ceea ce, după părerea noastră, este oricum evident: art. 215 alin. 1 teza finală C.pr.civ. impune fixarea de intervale orare orientative pentru fiecare cauză ori grupe mici de cauze. Teza corespunzătoare ar urma să fie aşadar reformulată în felul următor:

Lista va cuprinde şi intervalele orare orientative fixate pentru strigarea cauzelor. Intervalele orare vor fi fixate pentru fiecare dosar în parte ori pentru grupe mici de cauze, făcându-se mențiunea corespunzătoare pe citație.

În acest fel, orice discuții devin redundante și modificarea Regulamentului de ordine interioară al instanțelor judecătorești devine inutilă - oricum nici în prezent Regulamentul nu poate confirma ori infirma aplicarea Codului, act normativ de rang superior.

În mod corelativ acestei modificări, la art. 220 se va prevedea că:

Amânarea nu poate fi dispusă înainte de ora fixată orientativ în cauza respectivă, cu excepția situației în care la strigarea cauzei se prezintă toate părțile.

Totodată, la art. 201 alin.3 C.pr.civ., text care reglementează fixarea primului termen de judecată, se va preciza că:

Dispozițiile art. 215 alin.1 cu privire la fixarea intervalelor orare orientative pentru fiecare dosar în parte ori pentru grupe mici de cauze sunt aplicabile.

O modificare de esență şi cu caracter novator o constituie instituirea unei soluții flexibile la îndemâna instanței pentru a recurge, în situații întemeiate, la desfăşurarea ședinței de judecată prin videoconferință. În acest scop, la art. 213 ar urma să fie inserate 3 noi alineate:

În cazuri justificate, pentru a asigura soluţionarea cu celeritate a cauzei, evitarea riscurilor unei epidemii, participarea părților la proces, atunci când acestea se află la mare distanță ori din alte motive întemeiate deplasarea la sediul instanței ar fi dificilă ori în alte împrejurări similare, instanța, la cerere sau din oficiu, după consultarea părților, poate dispune ca procesul să se desfăşoare în întregime ori la anumite termene de judecată prin videoconferință.

Alin.4 În cazurile prevăzute de alin.3, se va asigura transmiterea audio și video pentru toate părțile, reprezentanții lor, cei care îi asistă pe minori, apărătorii părților, martorii, experții, traducătorii, interpreții precum și a altor persoane cărora instanța, pentru motive 
temeinice, le admite să asiste la procesul desfăşurat prin videoconferință.

Alin.5: În cauze care prezintă un larg interes public, instanța poate dispune, după ascultarea părților, ca dezbaterile asupra fondului urmate prin videoconferință să fie transmise în direct pe portalul instanței.

În ce ne privește nu subscriem nici viziunii în care perceperea fizică a adversarului în sala de ședință ar fí importantă - procesul este o succesiune tehnică de acte de procedură și nu un turnir - nici aceleia în care simpla posibilitate de a se recurge la videoconferință ori la soluționarea cauzei fără citare ar echivala cu o presiune implicită din partea instanței pentru a accepta aceste soluții. Instanțele judecătorești au exercițiul cotidian al imparțialităţii și nu pot fi suspectate a avea interesul de a impune anumite soluții în detrimentul altora, așa cum tot cotidian trebuie să facă distincția între soluția legală și impresiile personale asupra conduitei părților și a reprezentanților lor. Pe de altă parte, avocații și ceilalți profesioniști ai dreptului sunt suficient de puternici moralmente și de independenţi pentru a nu se lăsa intimidați și presaţi de vreo instanță judecătorească. Asemenea considerente empirice - precum simțitul și mirositul din sala de ședință ca strategie avocațială - nu pot fi contrapuse în mod serios necesității stringente de a moderniza procedurile judiciare, pentru a le face mai sigure și mai rapide. De asemenea, extinderea spațială a posibilităţii de a apela la servicii avocaţiale în contextele speciale evocate de textul propus - căci videoconferinţa nu va deveni, totuşi, procedura de drept comun - este mai degrabă un argument favorabil soluţiei pe care o propunem, fiind de natură a stimula concurența, benefică în orice domeniu.

Totodată, sunt necesare modificări pentru a da conținut dispozițiilor generale ale art. 15 C.pr.civ., care proclamă că părțile pot solicita expres ca soluționarea cauzei să se facă numai în raport de actele dosarului, așadar, fără citare; acest text important nu are însă reverberații suficiente în prevederile care reglementează judecata. De aceea, propunem inserarea unui nou art. $213^{1}$ C.pr.civ., potrivit cu care:

Art. $213^{1}$ (1) În cazurile în care părțile solicită expres instanței ca judecata să se facă numai pe baza actelor depuse la dosarul cauzei, instanța poate dispune soluționarea cauzei fără citarea părților. În această situație, instanța va înștiința părțile prin mijloacele prevăzute de art. 241 alin.3 cu privire la termenul limită pentru depunerea actelor în probaţiune.

(2) Toate cererile și actele depuse de părți în dosarele soluționate fără citarea părților, în condițiile alin.(1) se comunică direct între acestea, dovezile corespunzătoare fiind depuse la dosarul instanței odată cu cererea ori cu înscrisurile respective.

(3) Instanța va pronunța și redacta hotărârea în termen de 30 de zile de la primirea tuturor informațiilor necesare ori, după caz, de la 
expirarea termenului prevăzut la alin.(1). Dispozițiile art. 426 alin.(5)

se aplică în mod corespunzător.

Dacă este adoptată această soluție, la art. 15 și art. 153 C.pr.civ. trebuie inserate trimiteri corespunzătoare la noul text.

Având în vedere că, din punct de vedere practic, solicitarea expresă a soluționării cauzelor fără citare va rămâne excepția - căci partea întotdeauna va prefera adoptarea soluției prevăzută de lege cu titlu de drept comun și se va feri de soluții derogatorii ori pur și simplu nu va cunoaște textul, se pot imagina diferite grade de atenuare practică a regulii de soluționare a cauzelor cu citarea părților, după cum urmează:

Art. 213 alin. $1^{1}$ : Acordul părților cu privire la soluționarea cauzei în condițiile alin.1 se prezumă, cu excepția cazului în care se solicită expres și motivat soluționarea cauzei în ședință publică.

Într-o variantă mai restrictivă, această prezumţie poate fi limitată la stat, unitățile administrativ-teritoriale, autorități și instituții publice.

De asemenea, această prezumţie poate fi instituită cu titlu temporar, pentru o perioadă de 1-2 ani (dar și proceselor în curs), pentru a rezolva stocul de dosare acumulat în contextul pandemiei. Personal îl vedem util și cu titlu de soluție permanentă, deși admitem că este și o soluție curajoasă.

Extinderea cauzelor care pot fi soluționate și fără citare, la aprecierea instanței, ar trebui să cuprindă și o seamă de incidente procedurale, precum: strămutarea, discutarea cererii de suspendare a executării hotărârii atacate până la judecarea căii de atac, reexaminarea împotriva amenzii judiciare, reexaminarea împotriva soluţiei de anulare a cererii de chemare în judecată în procedura de regularizare etc.

O altă modificare de esenţă care reclamă însă cu precădere investiţii serioase în baza materială a instanțelor și doar subsecvent reglementări legale cu un termen realist de punere în aplicare (2-5 ani) este trecerea completă la un sistem de dosar electronic, înțeles ca un sistem în care dosarul nu mai există fizic (decât eventual ca variantă printată pentru uzul propriu al instanței, respectiv al părților, care vor avea fiecare exemplare pentru studiu mai facil, dacă doresc), ci este administrat exclusiv electronic.

Desigur, o asemenea măsură deja adoptată ori în curs de adoptare în multe state europene (precum Olanda sau Germania) presupune în primul rând investiții serioase în baza materială a instanțelor (ecranele mari de tip touch screen pe pupitrul sălilor de ședință, în care dosarele pot fi "răsfoite" în timp real sunt doar un element care ne vine în minte spontan), în măsuri de siguranță informatică și în conexiuni securizate dintre instanțe și liber profesioniștii profesiilor partenere, precum avocații, practicienii în 
insolvență ori executorii judecătorești ${ }^{13}$. Urmând exemplul, altor legislații, legiuitorul le poate impune acestora ca, într-o etapă tranzitorie determinată, să se doteze cu o conexiune securizată care să presupună autentificare și semnături electronice, dotarea obligatorie cu o adresă de e-mail la care să fie valabil comunicate toate actele de procedură, prin asimilare cu actele primite personal sau prin funcționarul însărcinat cu primirea corespondenței, sesizarea instanțelor judecătorești doar pe cale electronică și atașarea în format fizic, dacă este cazul, doar a înscrisurilor mai voluminoase etc. Acest efort ar urma să fie facilitat prin instituirea unor facilităţi de ordin fiscal. Aceste obligații trebuie impuse și tuturor autorităților și instituțiilor publice, precum și, etapizat și diferențiat, tuturor persoanelor juridice.

Mai problematică rămâne situația persoanelor fizice, căci în România, spre deosebire de alte sisteme care au putut trece la sistemul descris de dosar electronic mult mai uşor tocmai pentru că asistența avocațială este impusă prin lege, persoanele fizice pot sesiza direct instanța și pot participa personal la procedurile judiciare. Or, la prima vedere, poate părea excesivă obligativitatea folosirii unor mijloace informatice în cazul unei persoane fizice. Pe de altă parte, ele sunt folosite oricum în practică (în cvasitotalitatea cauzelor fiind depuse cereri tehnoredactate și imprimate și foarte rar cereri olografe), iar o adresă de e-mail dețin probabil majoritatea cetățenilor români.

Sugerăm aşadar instituirea unui termen mai lung (2023-2025) până la care persoanele fizice să fie obligate să dețină o adresă de e-mail pentru comunicările cu instanța judecătorească.

În această materie, legiuitorul va trebui să menţină alternativa sesizării instanţei în forma clasică, pentru a nu restrânge accesul la justiție al celor care nu dețin ori nu pot folosi computerul, păstrând astfel și obligativitatea depunerii cererii semnate olograf, în original, de către cei care nu dețin semnătură electronică.

Trecerea la dosarul ținut și administrat în totalitate electronic implică un efort organizatoric și financiar notabil, poate de nivelul sutelor de milioane de euro. Totuși, economia realizată pe termen lung, prin eliminarea utilizării unor cantități impresionante de hârtie, a comunicărilor prin poșta clasică, a stocării dosarelor în format fizic, a transportului dosarelor între instanțe, instanțe și parchete etc., câștigul incontestabil de timp - dosarul fiind bunăoară transferat la instanța superioară printr-un simplu click și nu în ultimul rând protecția mediului (prin eliminarea consumului uriaș de hârtie, toner etc.) și a sănătății (nu mai există un dosar fizic cu microbi, potențial contagios) sunt argumente care fac ca acest efort să apară drept unul dezirabil și chiar necesar.

O altă direcție de reformă ar trebui să privească sistemul de ajutor public judiciar, actualmente acordat obligatoriu doar în contextul unor plafoane infime de venituri, care relevă o situație materială extrem de modestă, iar în rest, la aprecierea instanței de la caz

${ }^{13} \mathrm{Nu}$ am menționat aici consilierii juridici întrucât, aceștia desfășurându-și activitatea în cadrul unor raporturi de muncă în sens larg - fiind salariați sau funcționari publici - vor folosi dotările corespunzătoare ale persoanei juridice la care își desfășoară activitatea. 
la caz (art. 8 din OUG nr. 51/2008). Reamintim că, atunci când - neinspirat, credem noi în continuare - Curtea Constituțională a declarat neconstituțională asistența avocațială obligatorie în fața instanțelor de recurs, criticile sale au privit mai puțin soluția în sine, cât sistemul de ajutor public judiciar, neadecvat acestei soluții. Putem reinterpreta creativ hotărârea Curții ca fiind o hotărâre de tip Solange...(atâta timp cât $)^{14}$, în sensul că neconstituționalitatea subzistă în condițiile în care legea ajutorului public judiciar nu este armonizată cu o atare exigență.

Așadar, în ce ne privește, credem că accesul la justiție în cauzele mai simple, frecvente și de mize patrimoniale mici și medii poate fi facilitat prin competența de primă instanță a judecătoriei, ale căror hotărâri să fie supuse numai apelului la tribunal, în vreme ce în materiile specializate, competența de primă instanță trebuie să aparțină tribunalului sau chiar curții de apel (contencios administrativ și fiscal, proprietate intelectuală, litigii societare, dreptul concurenței, litigii civile de peste o anumită valoare, materia electorală, litigiile de muncă etc.), iar în aceste cauze, de principiu, asistența avocațială trebuie să fie obligatorie (cu excepții de ordin social precum anumite categorii de litigii de muncă și securitate socială) ${ }^{15}$, însă cu acordarea unei posibilități foarte extinse de a obține în prealabil litigiului și pe parcursul acestuia ajutor public judiciar prin plata onorariului avocațial de către stat, în anumite plafoane (avocatul urmând așadar fie a fi desemnat gratuit pentru parte, fie a fi ales de parte, care ar urma să plătească eventuala diferență de onorariu avocatului dorit de ea). De altfel, extinderea posibilităților de acordare a ajutorului public judiciar trebuie să se refere și la situațiile in care partea nu poate participa la videoconferință ori nu deține mijloacele materiale

14 În hotărârea Solange II (citare oficială (22 October 1986) BVerfGE 73, 339, [1987] 3 CMLR 225), Tribunalul Constituțional german a hotărât în esență că nu-și va mai exercita puterea jurisdicțională de a controla actele de putere publică germane adoptate în temeiul legislației secundare europene, în condițiile în care sistemul de drept al Comunităților Europene (care aderaseră între timp și la CEDO) oferă o protecție a drepturilor fundamentale echivalentă celei oferite de Legea fundamentală germană. În acest fel, a fost abandonată soluția mai veche din cauza Solange I (29 May 1974, BVerfGE 37, 271 [1974] CMLR 540), în care s-a statuat dimpotrivă că aceste acte sunt supuse controlului instanței constituționale germane, în raport de stadiul incipient al protecției drepturilor fundamentale în Comunităţile Europene (la acea vreme).

${ }^{15} \mathrm{Cu}$ ocazia prezentării am încercat o analogie cu sistemul sanitar, existând mai multe nivele de acordare a asistenței medicale, de la medicul de familie și unitățile sanitare de proximitate până la spitalele de urgență și cele specializate. În domeniul justiției trebuie să ne despărțim de concepția potrivit căreia oricine are acces oricând şi în orice condiții la orice instanțe judecătorești, nesocotind reguli procedurale și formulând abuziv o seamă de cereri de natură a greva sistemul judiciar. Ne propunem să examinăm cu altă ocazie cum tratează sistemele de drept comparat situațiile patologice, ale așa-numitor procesomani, dar și strategii curente care relevă abuzul de drept. Totodată, credem că este utilă instituirea (prin lege, regulament ori cu titlu de bune practici a) unui sistem de fast track, urmând a fi prioritizate cauze importante (de exemplu, cele în care se ridică pentru prima oară o problemă de drept de interes general, cu vocația de genera multe cauze repetitive ori de interes social acut), urgente sau foarte vechi, prin derogare de la ordinea normală de fixare a termenelor, de regulă în considerarea vechimii cauzei. 
pentru accesarea electronică a dosarului, situații în care desemnarea unui avocat pare de asemenea o soluție justă. În același timp însă trebuie întărite mecanismele pentru contracararea abuzului de drept în formularea cererilor, inclusiv a celor repetitive și neprobate de ajutor public judiciar.

\section{Concluzii}

Pandemia cu coronavirusul SARS-COV2 prezintă riscuri fără precedent pentru funcționarea normală a justiției și, prin aceasta, chiar pentru statul de drept. Aceste riscuri sunt pe deplin actuale. Spre deosebire de alte perioade, există însă și resursele tehnice, financiare și cognitive necesare pentru a atenua impactul negativ al crizei de sănătate publică și a o transforma în oportunitatea realizării unor reforme și modernizări îndelung amânate.

Ne-am dori ca, în loc să celebrăm zile instituite pur formal întru amintirea faptului că există justiție în țara noastră, în locul unor discursuri politicoase și de circumstanță, factorii de decizie, de la Ministerul Justiției și până la Consiliul Superior al Magistraturii, să se angajeze energic în reformarea modului în care justitiia funcționează în concret, pentru a îmbunătăți condițiile și siguranța la locul de muncă, respectiv calitatea serviciului public pentru justițiabili.

Reformele legislative schițate mai sus sunt doar o secvență dintr-un program care poate și trebuie să fie mult mai amplu și să cuprindă și aspecte foarte prozaice, dar esențiale precum modernizarea, extinderea, construirea sediilor de instanță (mult clamatul "Cartier al Justiției" devenind o glumă similară celor cu metroul din Drumul Taberei, în lipsa oricăror demersuri reale precum exproprieri, planuri de urbanism, concursuri de arhitectură etc.), informatizarea instanțelor pentru a trece cu adevărat la dosarul administrat electronic într-un orizont de aproximativ 5 ani. Abia după ce toate aceste etape vor fi fost parcurse vom avea, poate, ceva de sărbătorit, anume că am reușit să ducem mai departe ceea ce înaintașii noștri au conturat încă din secolele trecute, respectiv, cu prea puține modificări de substanță, modul de funcționare a justiției noastre.

Materialul a fost publicat în revista online a Facultății de Drept, $\underline{\text { AUBD - Forum Juridic nr. }}$ $\underline{2 / 2020 .}$ 